\section{Declaration and Handling of Conflicts of Interest in Guidelines}

by Dr. med. Gisela Schott, Prof. Dr. med. Klaus Lieb, Dr. sc. hum. Jochen König, Prof. Dr. med. Bernd Mühlbauer, Prof. Dr. med. Wilhelm Niebling, Dipl.-Biol. Henry Pachl, Stephan Schmutz and Prof. Dr. med. Wolf-Dieter Ludwig in issue $26 / 2015$

\section{Common Sense of Proportion Missing}

Without any doubt it is correct that the Association of the Scientific Medical Societies in Germany (Arbeitsgemeinschaft der Wissenschaftlichen Medizinischen Fachgesellschaften e.V., AWMF) asks authors of medical guidelines to disclose any potential conflicts of interest; however, it seems that common sense of proportion is missing in Germany as each potential conflict of interest has to be declared regardless of the corresponding financial value. Here are some examples for this in my opinion unreasonable request for complete political correctness:

- Company A contributes financially to the purchase of an ultrasound scanner which can be used by all colleagues working in the department

- At a congress, company B invites attendees to dinner

- Stock of company C is part of the investment portfolio of a medical pension scheme

- Company D-Lunch symposium-reimbursement of expenses, no fees

- Co-investigator in a multicenter study of company E, placebo arm, EUR 100 per patient.

Regarding this issue, our colleagues in the United States are much more down to earth: for most journals, they have introduced a financial threshold to assist in the evaluation of potential significant conflicts of interest. Currently, this is set at USD 10000 per annum (1):

"A relationship is considered to be "significant" if (a) the person receives 10000 US-Dollar or more during any 12-month period, or $5 \%$ or more of the person's gross income; or (b) the person owns $5 \%$ or more of the voting stock or share of the entity, or owns 10000 USDollar or more of the fair market value of the entity."

Of course, there is room for discussion about where this threshold should be in Germany. Nevertheless, a clear statement on this matter by the professional societies, including the AWMF, which reinstates the required common sense of proportion and thus puts a stop to this excessive and unhelpful regulation, is long overdue (2). No colleague invited to a lunch or dinner once or twice has a potential or significant conflict of interest when it comes to producing a scientific guideline.

DOl: 10.3238/arztebl.2016.0175a

\section{REFERENCES}

1. Giglia TM, Massicotte MP, Tweddell JS, et al.: Prevention and treatment of thrombosis in pediatric and congenital heart disease: a scientific statement from the American Heart Association. Circulation 2013; 128: 2622-703.
2. Schott G, Lieb K, König J, et al.: Declaration and handling of conflicts of interest in guidelines - a study of $S 1$ guidelines from German specialist societies from 2010-2013. Dtsch Arztebl Int 2015; 112: 445-51.

Prof. Dr. med. Nikolaus A. Haas

Abteilung für Kinderkardiologie und Pädiatrische Intensivmedizin

Klinikum der Universität München (LMU)

Nikolaus.Haas@med.uni-muenchen.de

\section{We Are Making no Progress}

The article of Schott et al. shows that we have not made any progress for years: Guideline authors do indeed declare their conflicts of interest, but this has no impact on their involvement in developing a guideline (1). In the United States, far more progress has been achieved in tackling this matter. The large professional societies in the US require that lead guideline authors and at least half of those involved have no conflict of interest at all. Furthermore, authors with conflicts of interest have to abstain from voting (2). Meanwhile, divestment is being discussed there, i.e. the severing of financial ties with the industry before an authors is appointed to a guideline group. This development is triggered by the understanding that contractual work for a manufacturer and the evaluation of their products should not be in one hand. In Germany, too, this discussion has gained momentum. Within a few months, more than 1200 doctors signed the "Appeal for Independent Guidelines", calling on the AWMF and the professional societies to define clear rules for the handling of conflicts of interest (3). We should not delay this for too long as the scientific foundation and credibility of our guidelines are at stake.

DOl: 10.3238/arztebl.2016.0175b

\section{REFERENCES}

1. Schott G, Lieb K, König J, et al.: Declaration and handling of conflicts of interest in guidelines - a study of $S 1$ guidelines from German specialist societies from 2010-13. Dtsch Arztebl Int 2015; 112: 445-51.

2. Council of Medical Specialty Societies. Code for interactions with companies. www.cmss.org/codeforinteractions.aspx. (Last accessed on 20 October 2015).

3. NeurologyFirst: Appell an die medizinischen Fachgesellschaften in Deutschland zum Umgang mit Interessenkonflikten. www.neurology first.de/appell (last accessed on 20 October 2015).

\section{Prof. Dr. med. Thomas Lempert}

Abteilung für Neurologie

Schlosspark-Klinik, Berlin, Germany

thomas.lempert@schlosspark-klinik.de

\section{In Reply:}

In his letter, PD Dr. Haas calls for the introduction of a financial threshold to help define a conflict of interest. He points to the colleagues in den US and refers to a guideline of the American Heart Association (1). In this guideline, all amounts exceeding USD 10000 are classed as significant. However, 
smaller amounts must be declared as well-they are classed as modest.

There is no lower limit to the influence exerted by gifts - this has been proven by scientific studies about reciprocity (2). Therefore, we hold the opinion that authors should be asked to declare benefits regardless of the amount. By virtue of the principle of reciprocity we feel obliged to repay favors, gifts, invitations and the like. This is used by pharmaceutical companies to influence the prescription behavior of physicians. The rule of reciprocity works almost independently of the value of what has been given. There is no threshold value below which an influencing effect becomes less likely or can be excluded. As a matter of fact, persons who think that they cannot be influenced are even more susceptible to being influenced: The illusion of invulnerability leads to inadequate resistance to attempts of manipulation.

When dealing with conflicts of interest, it is essential to document them in the first place; then they should be evaluated by a third party and finally, and most importantly, the detection of a conflict of interest must have consequences. In the United States, the rules regarding the transparency of financial relationships between pharmaceutical companies and physicians are particularly strict. For example, based on the provisions of the Physician Payment Sunshine Act, as of September 2014 any benefits provided by pharmaceutical manufacturers or manufacturers of medical devices to physicians and teaching hospitals in excess of 10 dollars in value are published (www.cms.gov/openpay ments/), including consultancy and lecture fees, financial support for research and teaching, travel and entertainment expenses, shares and dividends. In Germany, the Code of Transparency of the Association of Voluntary Self-Control of the Pharmaceutical Industry (FSA, Verein Freiwillige Selbstkontrolle für die Arzneimittelindustrie e. V.) is effective (www.fsa-pharma.de/). Pursuant to this code, as of 2016, any non-cash benefits provided to physicians and other healthcare professionals are to be published; however, unlike in the US where there is one central website, it is expected that these benefits will be posted on the respective company websites. In contrast to the United States, in Germany physicians have to agree to this information being published.

We like to thank Prof. Dr. Lempert for his valuable additional information on key developments in the handling of conflicts of interest in the context of the creation of guidelines in the United States. Proposals for how to deal with conflicts of interest have been made in the US for other areas of medicine as well, including research and basic and advanced training and continuing medical education (3). These have been a source of inspiration to the discussion in Germany (4, 5) and led, for example, to the introduction of rules regarding the handling of conflicts of interest by the Drug Commission of the German Medical Association (www.akdae.de/Kommission/Organisation/Statuten/Inter essenkonflikte/Regeln.pdf).

What we have to do now is to follow these rules and make certain that declared conflicts of interest have consequences - to ensure optimum care for patients.

DOI: 10.3238/arztebl.2016.0175c

\section{REFERENCES}

1. Giglia TM, Massicotte MP, Tweddell JS, et al.: Prevention and treatment of thrombosis in pediatric and congenital heart disease: a scientific statement from the American Heart Association. Circulation 2013; 128: 2622-2703.

2. Klemperer D: Interessenkonflikte: Gefahr für das ärztliche Urteilsvermögen. Dtsch Arztebl 2008; 105: A 2098-100.

3. Committee on Conflict of Interest in Medical Research, Education, and Practice, Institute of Medicine: Lo B, Field MJ, (eds.): Conflict of interest in medical research, education, and practice. $1^{\text {st }}$ edition, Washington D.C.: National Academies Press 2009.

4. Lieb K, Klemperer D, Ludwig WD (eds.): Interessenkonflikte in der Medizin: Hintergründe und Lösungsmöglichkeiten. Berlin, Heidelberg: Springer-Verlag 2011

5. Schott G, Lieb K, König J, et al.: Declaration and handling of conflicts of interest in guidelines - a study of $\mathrm{S} 1$ guidelines from German specialist societies from 2010-2013. Dtsch Arztebl Int 2015; 112: 445-51.

\section{Dr. med. Gisela Schott, MPH}

Arzneimittelkommission der deutschen Ärzteschaft

Berlin, Germany

gisela.schott@akdae.de

Conflict of interest statement

The authors of all contributions declare that no conflict of interest exists. 